\title{
Molecular, Physiological, and Host-Range Characterization of Acidovorax avenae subsp. citrulli Isolates from Watermelon and Melon in Israel
}

\author{
Saul Burdman and Nadia Kots, Department of Plant Pathology and Microbiology, The Hebrew University of Jeru- \\ salem, P.O. Box 12, Rehovot 76100, Israel; Giora Kritzman, Department of Plant Pathology, Agricultural Research \\ Organization, The Volcani Center, P.O. Box 6, Bet Dagan 50250, Israel; and June Kopelowitz, Savyon Diagnostics \\ Ltd., 3 Habosem St., Ashdod 77610, Israel
}

\begin{abstract}
Burdman, S., Kots, N., Kritzman, G., and Kopelowitz, J. 2005. Molecular, physiological, and host-range characterization of Acidovorax avenae subsp. citrulli isolates from watermelon and melon in Israel. Plant Dis. 89:1339-1347.

Bacterial fruit blotch (BFB), caused by Acidovorax avenae subsp. citrulli, is a serious disease of cucurbit plants. The first important occurrence of BFB in Israel was during 2000 to 2003 on watermelon and melon. Twelve bacterial isolates associated with these outbreaks were confirmed as A. avenae subsp. citrulli by pathogenicity assays, gas chromatography of fatty-acid methyl esters, and substrate-utilization profiles. The isolates were characterized in terms of their aggressiveness in different hosts by seed, seedling, and fruit inoculations, and according to their DNA fingerprinting profiles using pulse-field gel electrophoresis (PFGE) and repetitive-PCR approaches. Results from the present work agree with previous studies supporting the existence of two differentiated groups within A. avenae subsp. citrulli, one including strains that are more associated with watermelon (group II), the other consisting of strains that are usually associated with nonwatermelon cucurbits (group I). This study indicates that isolates from both groups have been introduced to Israel. PFGE analysis revealed that the 12 analyzed isolates can be divided into five different haplotypes, of which four were previously unreported. Additional differentiating features between group I and II strains are presented.
\end{abstract}

Additional keywords: Citrullus lanatus, Cucumis melo, Cucurbitaceae

The gram-negative bacterium Acidovorax avenae subsp. citrulli, formerly Pseudomonas pseudoalcaligenes subsp. citrulli, is the causal agent of bacterial fruit blotch (BFB) of cucurbits $(22,30)$. Although the disease was first reported in 1965 in watermelon seedlings of several plant introduction lines in Georgia, in the United States (24), BFB gained importance after devastating outbreaks in watermelon fields in the Mariana Islands (28), Indiana (13), and Florida (23) in the late 1980s. Since then, BFB has emerged as a major threat to watermelon in the southeastern and midwestern United States. In recent years, significant economic losses caused by $A$. avenae subsp. citrulli on other cultivated cucurbits, including melon, cucumber, squash, and pumpkin, have been reported in many parts of the world, including the United States, Nicaragua, Costa Rica, Brazil, Australia, Turkey, Japan, Korea, Thailand, Taiwan, and China $(7,8,11,15,18,21,25)$.

Corresponding author: S. Burdman

E-mail: saulb@agri.huji.ac.il

Accepted for publication 9 July 2005.

DOI: 10.1094/PD-89-1339

(C) 2005 The American Phytopathological Society
A. avenae subsp. citrulli can be highly destructive. Under favorable conditions, the bacterium spreads rapidly throughout transplant houses and in the field, leading to seedling blight and/or fruit rot. Chemical control of BFB has been ineffective $(10,19,21,24)$, and complete/monogenic disease resistance is not currently available in commercial cultivars. A. avenae subsp. citrulli is transmitted by seeds that usually serve as the primary source of inoculum for BFB outbreaks $(6,21)$.

Although chemical treatments can reduce $A$. avenae subsp. citrulli populations in infested seeds, they fail to eradicate the bacterium $(5,21)$. Therefore, the main strategy for combating BFB is the elimination of infested seed lots prior to planting. Several seed assays for A. avenae subsp. citrulli detection have been developed; however, all have limitations $(21,26)$. Because of the costly lawsuits filed by growers against watermelon seed companies, BFB represents a serious threat to the watermelon industry. For instance, in the mid1990s, to avoid costly litigation, several seed companies in the United States suspended the sale of watermelon seeds in several southeastern states that were considered to be at high risk for BFB outbreaks $(12,21)$.

Based on pathogenicity assays, analyses of DNA fingerprinting profiles, and whole- cell fatty-acid analyses of many isolates, Walcott et al. $(25,27)$ confirmed previous evidence $(18,23)$ indicating that $A$. avenae subsp. citrulli strains can be divided into at least two well-differentiated groups: group I includes strains that were mainly isolated from nonwatermelon cucurbits and the species type strain, ATCC29625, which was isolated from watermelon PI lines (22); group II includes the typical watermelon BFB-causing strains that were responsible for the late 1980s outbreaks in the United States. It was also suggested that inconsistent results from different attempts to screen watermelon varieties for BFB resistance could be due, at least in part, to significant differences in aggressiveness between group I and II strains (27).

In Israel, a strange phenomenon of seedling collapse was observed in a few spots of a single watermelon field in the southern part of the Golan Heights region in 1979. Bacteria isolated from diseased seedlings were shown to be aggressive on watermelon, and several biochemical assays showed the highest similarity to $P$. pseudoalcaligenes subsp. citrulli (G. Kritzman, unpublished data). Later, A. avenae subsp. citrulli was intercepted in imported watermelon seeds in the years 1992 to 1994 (1). Interestingly, the pathogen was shown to be transmitted by solanaceous seeds since the bacterium was isolated from several shipments of tomato seeds imported to Israel, and from eggplant seedlings grown from imported seeds (2). Natural BFB outbreaks occurred in several watermelon and melon fields and greenhouses from different Israeli regions during 2000 to 2003 , causing economic losses, especially in 2002. The objective of this work was to characterize A. avenae subsp. citrulli isolates associated with these outbreaks in terms of aggressiveness, DNA fingerprinting profiles, and several biochemical features.

\section{MATERIALS AND METHODS}

Bacterial isolates. Bacteria were isolated from leaves, fruits, and seeds of watermelon and melon from five fields and three greenhouses located at different geographical regions, as well as from rotted fruits from a local market, during 2000 to 2003 (Table 1). Following preliminary pathogenicity testing, 12 isolates, named 
W1 to W6 and M1 to M6 for those isolated from watermelon and melon (Table 1), respectively, were selected for further characterization. Gas chromatographic analysis of fatty-acid methyl esters (GCFAME) was performed by the Israeli Plant Protection and Inspection Services (Volcani Center, Bet Dagan, Israel), according to described procedures (16), after growing bacteria on trypticase soy broth agar (TSBA; Difco Laboratories, Detroit, MI) for $24 \mathrm{~h}$ at $28^{\circ} \mathrm{C}$. GC-FAME similarity indexes were determined by statistical comparison to the MIDI TSBA40 library through the MIDI Sherlock Microbial Identification System (Midi Inc., Newark, DE). Carbon-source metabolic fingerprinting was carried out using the Biolog system, according to manufacturer's instructions (Biolog Inc., Hayward, CA). Biolog similarity indexes were determined by analysis of the data using the Microlog software (Biolog Inc.). A. avenae subsp. citrulli isolates were stored in $20 \%$ sterile glycerol at $-80^{\circ} \mathrm{C}$.

Growth curves, and physiological and biochemical assays. For growth curves, individual colonies from nutrient agar (NA; Becton, Dickinson and Co., Sparks, $\mathrm{MD})$ plates were used to inoculate $5-\mathrm{ml}$ nutrient broth (NB; Becton, Dickinson and Co.) starter cultures that were incubated at $28^{\circ} \mathrm{C}$ with shaking $(200 \mathrm{rpm})$ for $24 \mathrm{~h}$. Then, $1 \mathrm{ml}$ of each starter culture was added to $100 \mathrm{ml}$ of NB in 250-ml Erlenmeyer flasks. Cultures were grown as described and cell density was measured every $2 \mathrm{~h}$ in a Helios Gamma spectrophotometer (Thermo Electron Corp., Rochester, NY) at $600 \mathrm{~nm}$. Overall differences in growth curves between $\mathrm{M}$ and $\mathrm{W}$ isolates were assessed by logistic curve comparison using JMP software (JMP, Cary, NC). Extracellular enzyme activities were tested by growing cells for $48 \mathrm{~h}$ at $28^{\circ} \mathrm{C}$ on the following solid media: milk-agar $(70 \%$ $\mathrm{wt} / \mathrm{vol}$ skim milk in $2 \% \mathrm{wt} / \mathrm{vol}$ agar) for protease activity; $0.5 \%$ (wt/vol) starch in NA for starch hydrolysis; $0.5 \%$ (wt/vol) carboxymethylcellulose in NA for cellulase activity; and a medium containing 15 $\mathrm{g}$ of sodium polypectate, $3 \mathrm{~g}$ of trisodium citrate dehydrate, $0.8 \mathrm{~g}$ of $\mathrm{NaNO}_{3}, 0.3 \mathrm{~g}$ of $\mathrm{CaCl}_{2}, 50 \mathrm{mg}$ of sodium dodecyl sulfate, $0.75 \mathrm{mg}$ of crystal violet, and $0.2 \%$ agar for pectinase activity per liter. Activities were estimated by measuring the diameters of corresponding haloes around colonies. For starch hydrolysis, a few drops of IKI solution $(0.1 \mathrm{~g}$ of iodine and $0.2 \mathrm{~g}$ of $\mathrm{KI}$ per liter) were added to stain nonhydrolyzed starch in the medium. Each experiment was carried out at least twice. Positive and negative controls consisted of different species (local isolates) from our laboratory collection, including Bacillus megaterium (protease $^{+}$, starch hydrolysis ${ }^{+}$, pectinase $^{-}$), Serratia marcescens (protease $^{+}$, starch hydrolysis ${ }^{+}$, cellulase ${ }^{-}$, pectinase $^{-}$), Pectobacterium carotovorum subsp. carotovorum (cellulase ${ }^{+}$, pectinase $^{+}$), and Micrococcus sp. (protease ${ }^{-}$, starch hydrolysis ${ }^{-}$, cellulase ${ }^{-}$). Escherichia coli DH10B (Invitrogen, Carlsbad CA; starch hydrolysis ${ }^{-}$, cellulase ${ }^{-}$, pectinase ${ }^{-}$) was also utilized. To assess significant differences between $\mathrm{W}$ and $\mathrm{M}$ isolates, data were subjected to statistical analysis by $t$ test. Catalase activity was assessed by adding a few drops of $\mathrm{H}_{2} \mathrm{O}_{2}$ on 48-h-grown NA cultures. Sensitivity of isolates was assessed for the following antibiotics according to standard concentrations $(3,20)$ : ampicillin $(100 \mu \mathrm{g} / \mathrm{ml})$, cephalexin (30 $\mu \mathrm{g} / \mathrm{ml})$, chloramphenicol $(17 \mu \mathrm{g} / \mathrm{ml})$, and rifampicin $(40 \mu \mathrm{g} / \mathrm{ml})$.

Seedling pathogenicity assays. Threeweek-old seedlings of watermelon (Citrullus lanatus) cv. Malali (Hazera Genetics), melon (Cucumis melo var. reticulatus) cv. Ideal (Galia muskmelon type; Syngenta), melon (Cucumis melo var. cantalupensis) cv. 6404 (Ananas cantaloupe type, Hazera Genetics), and cucumber (Cucumis sativus) cv. Olympus (Syngenta), were inoculated with each of the 12 isolates. The plants were grown in $650-\mathrm{ml}$ plastic pots in a medium containing equal parts sand, peat, and vermiculite under standard greenhouse conditions $\left(25\right.$ to $\left.28^{\circ} \mathrm{C}\right)$. For inoculation, bacteria were grown on NA containing $100 \mu \mathrm{g} / \mathrm{ml}$ ampicillin for $48 \mathrm{~h}$ at $28^{\circ} \mathrm{C}$. Following resuspension in sterile water, bacterial suspensions were adjusted to $\sim 10^{8} \mathrm{CFU} / \mathrm{ml}$ using a spectrophotometer. Carborundum was added to the suspensions at $100 \mathrm{mg} / \mathrm{ml}$, and inoculation was performed by spreading the resulting mixture on one cotyledon and one of the true leaves of each seedling with a brush. Negative controls were seedlings treated with a mixture of sterile water and Carborundum. Seedlings were covered with plastic bags for $48 \mathrm{~h}$ to increase humidity, then the bags were removed and seedlings were kept in the greenhouse. Seven days after inoculation (DAI), the seedlings were scored based on a 0 to 4 disease index: 0 , no symptoms; 1 , slight water-soaking on cotyledon (water-soaking observed mainly on margins) and necrotic spots on true leaf; 2, massive water-soaking on cotyledon and necrotic spots on true leaf; 3, collapse of the infected cotyledon and/or leaf; and 4, spread of the infection to other leaves and collapse of the whole plant. Each isolate/host combination included four replicates (plants) per experiment. The experiment was carried out three times, and data were subjected to statistical analysis using nonparametric two-way analysis of variance.

Seed transmission assays. Seeds of watermelon cv. Malali, melon cv. 6404, and cucumber cv. Olympus were incubated in A. avenae subsp. citrulli suspensions $\left(10^{8}\right.$ $\mathrm{CFU} / \mathrm{ml})$ with gentle shaking (100 rpm) for $1 \mathrm{~h}$ at room temperature. Bacterial suspensions were prepared as indicated for seedling pathogenicity assays. Sterile water was used as a negative control. After incubation, suspensions were removed and seeds were gently washed with sterile water, air-dried for $4 \mathrm{~h}$ at room temperature, and sowed in 1.3-liter plastic pots containing sand for growth in the greenhouse at a temperature of 25 to $28^{\circ} \mathrm{C}$. Percentages of symptomatic seedlings and of seedling death were assessed 18 DAI. Each isolatehost combination included 12 plants distributed in two pots per experiment. The experiment was carried out twice, and data were subjected to analysis of variance with

Table 1. Acidovorax avenae subsp. citrulli isolates included in this study

\begin{tabular}{|c|c|c|c|c|c|}
\hline Isolate & Host and part of the plant & Geographical origin & Year collected $^{\mathrm{a}}$ & GC-FAME SI ${ }^{b}$ & Biolog SI ${ }^{\mathbf{b}}$ \\
\hline W1 & Watermelon, leaf from symptomatic plant & Dead Sea region & 2002 & 0.756 & 0.530 \\
\hline W2 & Watermelon, leaf from symptomatic plant & Northern Negev & 2003 & 0.731 & 0.540 \\
\hline W3 & Watermelon, fruit from symptomatic plant & Northern Negev & 2003 & 0.663 & 0.655 \\
\hline W4 & Watermelon, leaf from symptomatic plant & Golan Heights & 2002 & 0.694 & 0.595 \\
\hline W5 & Watermelon, rotted fruit from market & Central region & 2003 & 0.756 & 0.757 \\
\hline W6 & Watermelon, symptomatic seedling & Northern Negev & 2001 & 0.805 & 0.881 \\
\hline M1 & Melon, leaf from symptomatic seedling & Northern Negev & 2000 & 0.530 & 0.560 \\
\hline M2 & Melon, leaf from symptomatic plant & Northern Negev & 2002 & 0.825 & 0.780 \\
\hline M3 & Melon, fruit from symptomatic plant & Northern Negev & 2002 & 0.926 & 0.724 \\
\hline M4 & Melon, seeds from symptomatic plant & Northern Negev & 2002 & 0.620 & 0.805 \\
\hline M5 & Melon, rotted fruit from market & Central region & 2001 & 0.907 & 0.952 \\
\hline M6 & Melon, rotted fruit from symptomatic plant & Central region & 2002 & 0.806 & 0.622 \\
\hline
\end{tabular}

a All isolates were collected by G. Kritzman.

b SI (similarity index), similarity with A. avenae subsp. citrulli. GC-FAME SI was determined through statistical comparison with the TSBA40 library using the MIDI Sherlock Microbial Identification System. Biolog SI was determined through analysis with the Microlog software. For all isolates, A. avenae subsp. citrulli was the highest hit for both GC-FAME and Biolog profiles. 
isolates nested in groups ( $\mathrm{W}$ and $\mathrm{M}$ ), using JMP software.

Fruit pathogenicity assays. Mature fruits of watermelon (Citrullus lanatus) cv. Crimson Sweet and melon (Cucumis melo var. cantalupensis) cv. Ananas were purchased from a local market. A. avenae subsp. citrulli inoculum was prepared as previously described, and fruits were inoculated by injecting $1 \mathrm{ml}$ of bacterial suspensions at $10^{6}$ or $10^{8} \mathrm{CFU} / \mathrm{ml}$ with a 5-ml syringe through the rind, no deeper than $1 \mathrm{~cm}$. As negative controls, fruits were injected with sterile water. Following inoculation, the fruits were placed individually into plastic bags and incubated at 25 to $28^{\circ} \mathrm{C}$. After $48 \mathrm{~h}$, the bags were removed and fruits were arranged in separate plastic boxes. Symptom severity was evaluated 7 DAI according to a previously determined scale (25): 0 , no symptoms; 1 , small water-soaking lesions on the rind (surface lesions); 2, large lesions penetrating into the rind; 3 , lesions penetrating into the flesh of the fruit; 4 , extensive penetration and collapse of fruit tissues; 5, complete fruit rot. Each isolate was applied to three watermelon and melon fruits, at four and two different sites per fruit, respectively. The experiments were carried out twice, and data were subjected to statistical analysis using nonparametric two-way analysis of variance.

DNA digestions with SpeI and pulsedfield gel electrophoresis (PFGE). Bacteria were grown on NA at $28^{\circ} \mathrm{C}$ for $48 \mathrm{~h}$. Cells were suspended in a buffer containing $100 \mathrm{mM}$ EDTA and $100 \mathrm{mM} \mathrm{NaCl}(\mathrm{pH}$ 8.0), and adjusted to an $\mathrm{OD}_{600}$ of 0.3. Cells were pelleted at $10,780 \times g$ for $2 \mathrm{~min}$ and resuspended in $300 \mu \mathrm{l}$ of the same buffer, followed by the addition of $60 \mu \mathrm{l}$ of a 10 $\mathrm{mg} / \mathrm{ml}$ lysozyme solution. Preparation of agarose plugs and restriction with the rarecutting endonuclease SpeI (New England Biolabs, Beverly, MA) were done as described (27). PFGE was carried out in $15 \times$ $15 \mathrm{~cm} 1 \%$ Seakem Gold agarose gels using a CHEF DR-II apparatus (Bio-Rad, Hercules, CA). The gels were run in $0.5 \times \mathrm{TBE}$ buffer at a temperature of $14^{\circ} \mathrm{C}$. The SpeIdigested fragments were resolved as described (27). Concatemeric lambda DNA (New England Biolabs) was used as a marker. Following electrophoresis, gels were stained in an ethidium-bromide solution $(0.5 \mu \mathrm{g} / \mathrm{ml})$ and photographed with transmitted UV light at $295 \mathrm{~nm}$. Two independent PFGEs (from different restriction digestion reactions) were carried out for each isolate, with identical results.

Repetitive-PCR (Rep-PCR) fingerprinting. Genomic DNA was prepared from $1.5 \mathrm{ml}$ of a $24-\mathrm{h} \mathrm{NB}$ culture of $A$. avenae subsp. citrulli using the Wizard Genomic DNA Purification kit (Promega, Madison, WI). Primers REP1R-I and REP2-I (for repetitive extragenic palindrome-PCR; REP-PCR), ERIC1R and ERIC2 (for enterobacterial repetitive inter- genic consensus-PCR; ERIC-PCR), and BOXA1R (for BOX element-PCR; BOXPCR) were from IDT, Inc. (Coralville, IA), as described by Louws et al. (14). The PCR mixtures $(25 \mu \mathrm{l})$ contained: $1 \mathrm{U}$ of Red Taq Polymerase (Sigma Chemical Co., Saint Louis MO), $2.5 \mu$ l 10× buffer (Sigma), $2.5 \mu \mathrm{l}$ of $25 \mathrm{mM} \mathrm{MgCl} 2,0.2 \mu \mathrm{M}$ of each primer $(0.4 \mu \mathrm{M}$ of BOXA1R in BOX-PCR), $0.2 \mathrm{mM}$ of each dNTP (Promega), $2.75 \mathrm{mM}$ bovine serum albumin (Roche, Basel, Switzerland), and 20 ng of template DNA. Negative controls were PCR mixtures without template. Amplifications were performed in an Eppendorf Thermal Cycler (Eppendorf, Hamburg, Germany) with an initial denatura30 cycles of denaturation for $1 \mathrm{~min}$ at $94^{\circ} \mathrm{C}$, annealing for $1 \mathrm{~min}$ at 40,42 , or $53^{\circ} \mathrm{C}$ (for REP-, ERIC-, and BOX-PCR, respectively), and elongation at $65^{\circ} \mathrm{C}$ for 8 min. A final extension step was performed at $65^{\circ} \mathrm{C}$ for $16 \mathrm{~min}$. Samples of 12 to $15 \mu \mathrm{l}$ from each reaction were run in $1.5 \%$ agarose gels for $4 \mathrm{~h}$ at $60 \mathrm{~V}$. The gels were stained with an ethidium bromide solution $(0.5 \mu \mathrm{g} / \mathrm{ml})$ and photographed with transmitted UV light at $295 \mathrm{~nm}$. Three independent experiments were carried out for each Rep-PCR technique.

\section{RESULTS}

Identification of $A$. avenae subsp. citrulli isolates. Bacteria isolated from symptomatic watermelon and melon plants and fruits were tested in preliminary pathogenicity assays in the greenhouse (not shown), and 12 isolates were confirmed to be $A$. avenae subsp. citrulli by GC-FAME analysis and carbon substrate utilization profile analysis (Table 1). Isolates were designated $\mathrm{W} 1$ to $\mathrm{W} 6$ (W isolates) and M1 to M6 ( $\mathrm{M}$ isolates), for those isolated from watermelon and melon, respectively. tion cycle of $7 \mathrm{~min}$ at $95^{\circ} \mathrm{C}$, followed by

Carbon-source metabolic fingerprinting of isolates. Forty-four percent (42 of 95) of the substrates included in the Biolog plate were utilized by at least one isolate. All isolates utilized glycogen, D-galactose, methyl pyruvate, mono-methyl succinate, D-gluconic acid, $\beta$-hydroxybutyric acid, lactic acid, sebacic acid, bromo-succinic acid, L-asparagine, L-aspartic acid, Lglutamic acid, and L-pyroglutamic acid as sole carbon sources. All isolates except M1 grew on Tween 80 , D-fructose, and acetic acid. Other substrates that could be utilized by most isolates were Tween 40, Larabinose, L-proline, and 2-amino-ethanol. All W isolates, but not $\mathrm{M}$ isolates, grew on L-leucine, propionic acid, and $\alpha$-hydroxybutyric acid as sole carbon sources. A similar pattern was observed for $\alpha$-keto valeric acid and alaninamide, but in these cases, $\mathrm{W}$ isolates grew poorly. All W isolates, with the exception of W5, grew on Dglucose, whereas none of the $\mathrm{M}$ isolates grew on this carbon source. While all W isolates utilized $\alpha$-keto glutaric acid, only M3 utilized this carbon substrate. Further, all $\mathrm{W}$ isolates grew on L-serine, whereas only M2 and M3 used this carbon source among the $M$ isolates. Interestingly, only W2 utilized L-alanyl glycine, glycyl-Laspartic acid, and glycyl-L-glutamic acid. Based on the PFGE results, this isolate was later found to belong to a unique, unreported haplotype.

Growth curves, and physiological and biochemical assays. Figure 1 shows the growth curves of three $\mathrm{W}$ and three $\mathrm{M}$ isolates in $\mathrm{NB}$ at $28^{\circ} \mathrm{C}$. The other isolates showed similar growth patterns to those observed for their corresponding group (not shown). In general, all isolates showed similar growth curve dynamics, arriving at a density plateau after 18 to 20 $\mathrm{h}$ of growth, and no significant differences $(P=0.05)$ were found between $\mathrm{W}$ and $\mathrm{M}$

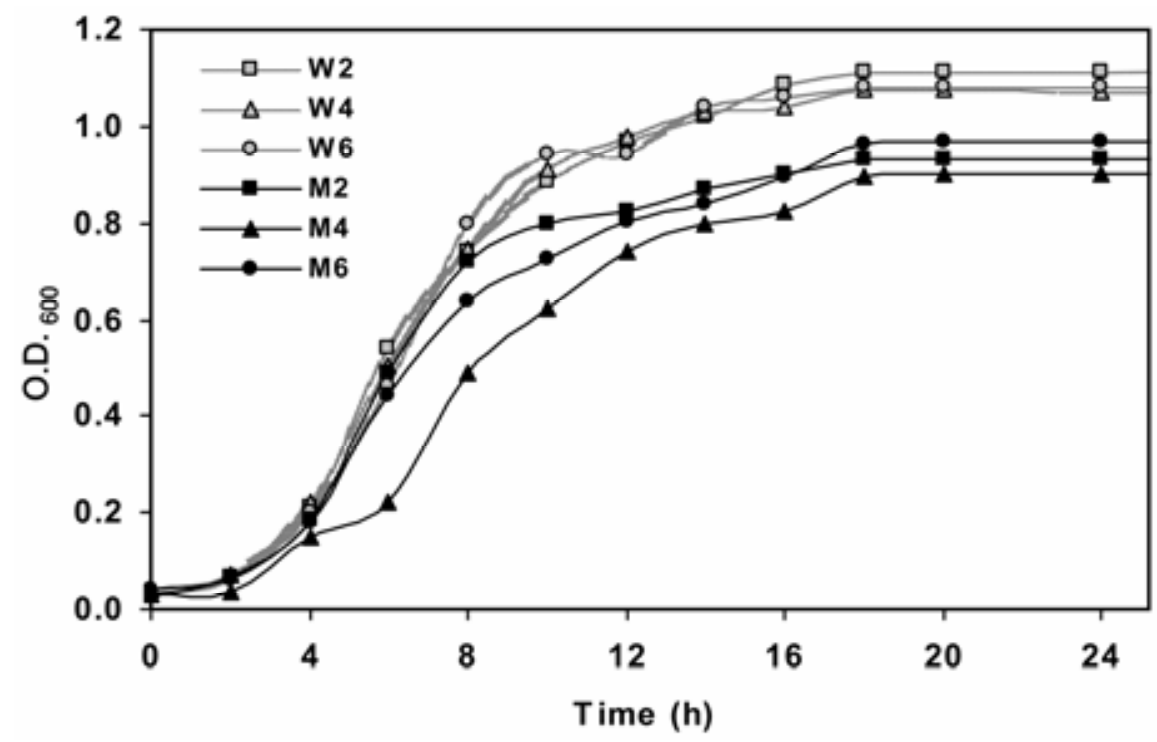

Fig. 1. Growth curves of Acidovorax avenae subsp. citrulli isolates W2, W4, W6, M2, M4, and M6 in nutrient broth $(\mathrm{NB})$ at $28^{\circ} \mathrm{C}$. 
isolate growth rates during the exponential phase (Fig. 1). However, W isolates showed a slightly extended exponential growth phase and reached significantly higher $(P=0.0002$; all isolates included in the statistical analysis) levels of absorbance than $M$ isolates. Similar differences in population growth among $\mathrm{W}$ and $\mathrm{M}$ isolates were also observed when isolates were grown at $37^{\circ} \mathrm{C}$ (not shown).

As expected from previous reports $(22,30)$, all isolates were positive for catalase test, negative for starch hydrolysis, and showed weak extracellular protease activity. Weak extracellular pectinase activity was also detected, with no significant differences $(P>0.05)$ among isolates (not shown). All isolates were positive for extracellular cellulase activity. Interestingly, $\mathrm{W}$ isolates showed significantly higher $(P$ $=0.0002)$ cellulase activity than $\mathrm{M}$ isolates: whereas $\mathrm{W}$ isolates showed an average halo diameter of $5.5 \pm 0.7 \mathrm{~cm}$, the average halo diameter for $\mathrm{M}$ isolates was $3.0 \pm 0.3 \mathrm{~cm}$ (average \pm standard deviation, as measured from the haloes produced in cellulase activity medium after 48 $\mathrm{h}$ of growth). All isolates were equally tolerant to ampicillin $(100 \mu \mathrm{g} / \mathrm{ml})$ and cephalexin $(30 \mu \mathrm{g} / \mathrm{ml})$, and sensitive to chloramphenicol $(17 \mu \mathrm{g} / \mathrm{ml})$. However, whereas all $\mathrm{M}$ isolates were sensitive to rifampicin $(40 \mu \mathrm{g} / \mathrm{ml})$, all $\mathrm{W}$ isolates were tolerant to this antibiotic.

Seedling pathogenicity assays. All tested cucurbits were susceptible to all isolates. However, differences in aggressiveness were observed. BFB symptoms appeared 3 DAI, and severity increased with time. They included water-soaking and necrotic brown lesions on cotyledons, and reddish-brown lesions on true leaves of melon and cucumber. Similar symptoms were observed in watermelon leaves, but the lesions were gray to black (Fig. 2). None of the seedlings inoculated with sterile water developed symptoms. The experiment effect on symptom severity was not significant $(P=0.66,0.35,0.42$, and 0.41 for watermelon, melon cv. 6404, melon cv. Ideal, and cucumber, respectively); hence, data from the three experiments were pooled for analysis. Results are shown in Table 2. $\mathrm{M}$ isolates were significantly more aggressive than $\mathrm{W}$ isolates on both melon cultivars and on cucumber $(P<0.0001$ for all cases $)$. On these hosts, M5 and M6 were found to be particularly aggressive. Among W isolates, $\mathrm{W} 1$ and $\mathrm{W} 6$ were found to be the least aggressive on melon (Table 2).

In contrast to melon and cucumber, a differential trend of aggressiveness among $\mathrm{M}$ and $\mathrm{W}$ isolates was not observed in watermelon, since the two groups did not differ significantly in this host $(P=0.43)$. Most isolates caused the collapse of inoculated cotyledons and leaves of watermelon seedlings 7 DAI. The exceptions were isolate W5, which was slightly less aggressive than the others, and W2, which was highly aggressive, leading to the rapid spread of infection and complete collapse of watermelon seedlings (Table 2).

Seed transmission assays. Two experiments were carried out. The effects of experiment on tested parameters were not significant $(P>0.90$ for all parameter and host combinations); therefore, data from the experiments were pooled for further analysis. The most remarkable finding was the $\mathrm{M}$ isolates' clearly higher aggressiveness relative to $\mathrm{W}$ isolates in all tested plants (Fig. 2, for isolates M6 and W1). Differences between $\mathrm{W}$ and $\mathrm{M}$ groups were statistically significant $(P<0.0001)$ for percentage of both symptomatic and
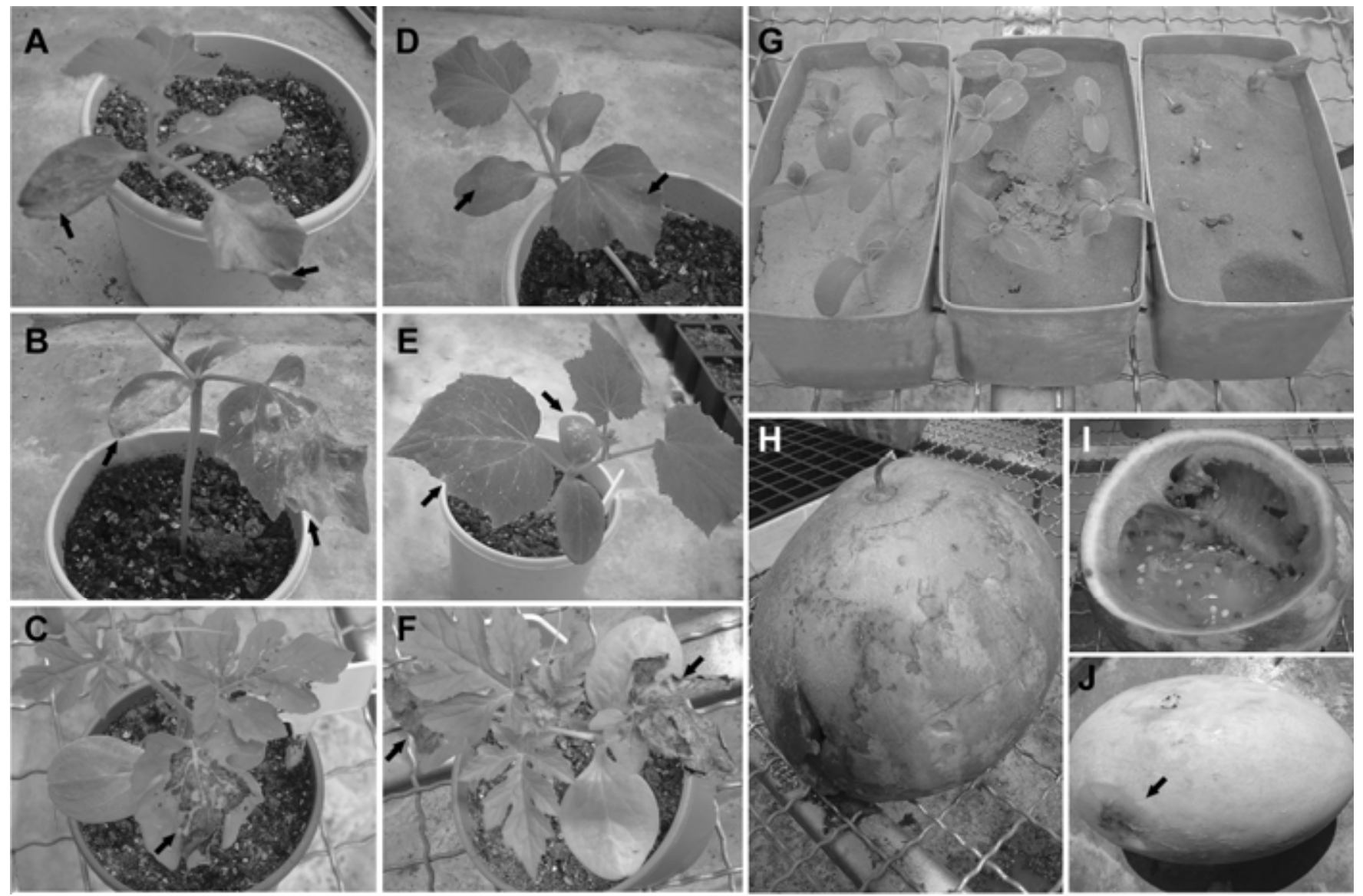

Fig. 2. Cucurbit plants inoculated with Acidovorax avenae subsp. citrulli by different methods. A to F, Foliar inoculation of 3-week-old seedlings. Bacterial suspensions $\left(\sim 10^{8} \mathrm{CFU} / \mathrm{ml}\right)$ were applied to cotyledons and leaves with a brush following addition of Carborundum. Melon cv. Ideal (A and D), cucumber cv. Olympus (B and E), and watermelon cv. Malali $(\mathbf{C}$ and $\mathbf{F})$ inoculated with isolates M6 (A to C) and W1 (D to F). Arrows indicate inoculated leaves. Pictures were taken 7 days after inoculation (DAI). G, Seed inoculation of melon cv. 6404 with bacterial suspensions of M6 (right), W1 (middle), or water (left). Seeds were inoculated with bacterial suspensions $\left(\sim 10^{8} \mathrm{CFU} / \mathrm{ml}\right)$ with gentle shaking for $1 \mathrm{~h}$; then they were gently washed with sterile water and air-dried before sowing. Picture was taken 10 days after sowing. Inoculation of detached fruits $(\mathbf{H}$ to $\mathbf{J})$. One milliliter of a $10^{6} \mathrm{CFU} / \mathrm{ml}$ suspension was injected through the rind of the fruits with a 5-ml syringe. Watermelon cv. Malali inoculated with W1 (H and I); melon (Ananas type) inoculated with M6 (J). Pictures were taken 5 DAI. 
dead seedlings in all tested hosts (Table 3 ). In watermelon, the percentage of mortality in seedlings inoculated with $\mathrm{M}$ isolates ranged from 72 to $90 \% 18$ DAI. Inoculation of seeds with these isolates induced water-soaking and coalescing lesions on cotyledons of emerging seedlings, which were usually followed by seedling death in watermelon seedlings from seeds inoculated with $\mathrm{W}$ isolates developed more slowly and to a lesser extent than with $\mathrm{M}$ isolates. Moreover, among W isolates, only W1 and W2 caused seedling death in watermelon, and this occurred for only 10 and $12 \%$ of the inoculated seedlings, respectively (Table 3).

Overall, melon did not significantly dif$\mathrm{M}$ isolates $(P=0.49$ for symptomatic seedlings; $P=0.71$ for seedling death): most melon and watermelon seeds inocua few days. In contrast, BFB symptoms on fer from watermelon in its response to the

lated with $\mathrm{M}$ isolates developed symptomatic seedlings, and in most cases, inoculation led to seedling death (Table 3). In contrast, most melon seeds inoculated with $\mathrm{W}$ isolates developed asymptomatic seedlings. Additionally, disease severity of melon seedlings inoculated with $\mathrm{W}$ isolates was significantly $(P<0.0001)$ lower than in watermelons inoculated with these isolates. In fact, W1, W4, and W5 did not induce symptoms at all, and the only W isolates to cause seedling death were W2 and W6, at very low rates (5 and $10 \%$, respectively). Similar findings were observed with two other cultivars of melon, Eden (Ananas type) and Galia (both from Hazera Genetics) (data not shown).

Cucumber seeds inoculated with $\mathrm{M}$ and $\mathrm{W}$ isolates developed a significantly $(P<$ $0.0001)$ higher percentage of symptomatic seedlings in comparison with watermelon and melon. However, seedling death for

Table 2. Summary of the results of pathogenicity assays of Acidovorax avenae subsp. citrulli isolates carried out with 3 -week-old seedlings ${ }^{\mathrm{a}}$

\begin{tabular}{lcccc}
\hline & \multicolumn{3}{c}{ Host } \\
\cline { 2 - 5 } Isolate & $\begin{array}{c}\text { Watermelon } \\
\text { cv. Malali }\end{array}$ & $\begin{array}{c}\text { Melon } \\
\text { cv. 6404 }\end{array}$ & $\begin{array}{c}\text { Melon } \\
\text { cv. Ideal }\end{array}$ & $\begin{array}{c}\text { Cucumber } \\
\text { cv. Olympus }\end{array}$ \\
\hline W1 & $3.0 \pm 0$ & $1.8 \pm 0.4$ & $1.7 \pm 0.5$ & $2.1 \pm 0.3$ \\
W2 & $4.2 \pm 0.4$ & $2.0 \pm 0$ & $2.1 \pm 0.3$ & $3.1 \pm 0.3$ \\
W3 & $3.0 \pm 0$ & $2.2 \pm 0.4$ & $2.1 \pm 0.3$ & $2.1 \pm 0.3$ \\
W4 & $2.3 \pm 0.5$ & $2.3 \pm 0.5$ & $2.0 \pm 0$ & $2.1 \pm 0.3$ \\
W5 & $2.0 \pm 0$ & $2.1 \pm 0.3$ & $1.9 \pm 0.3$ & $2.1 \pm 0.3$ \\
W6 & $3.1 \pm 0.3$ & $1.7 \pm 0.5$ & $1.1 \pm 0.1$ & $2.0 \pm 0$ \\
$W_{\text {Av }}$ & $2.9 \pm 0.6$ & $2.0 \pm 0.2$ & $1.8 \pm 0.2$ & $2.3 \pm 0.2$ \\
M1 & $3.0 \pm 0$ & $2.2 \pm 0.4$ & $2.4 \pm 0.5$ & $2.7 \pm 0.5$ \\
M2 & $3.0 \pm 0$ & $2.8 \pm 0.4$ & $2.1 \pm 0.3$ & $2.1 \pm 0.3$ \\
M3 & $2.6 \pm 0.5$ & $3.1 \pm 0.3$ & $3.1 \pm 0.3$ & $3.2 \pm 0.4$ \\
M4 & $3.1 \pm 0.3$ & $2.7 \pm 0.5$ & $3.1 \pm 0.3$ & $2.2 \pm 0.4$ \\
M5 & $3.1 \pm 0.3$ & $3.7 \pm 0.5$ & $3.6 \pm 0.5$ & $4.0 \pm 0$ \\
M6 & $2.4 \pm 0.5$ & $2.8 \pm 0.4$ & $3.8 \pm 0.4$ & $3.1 \pm 0.3$ \\
M $_{\text {Av }}$ & $2.9 \pm 0.3$ & $2.9 \pm 0.4$ & $3.0 \pm 0.5$ & $2.9 \pm 0.5$ \\
\hline
\end{tabular}

${ }^{\text {a }}$ Symptom severity was scored 7 days after inoculation according to the following disease index scale: 0 , no symptoms; 1, slight water-soaking on cotyledon (mainly on margins) and necrotic spots on true leaf; 2, massive water-soaking on cotyledon and necrotic spots on true leaf; 3, collapse of the infected cotyledon and/or leaf; and 4, spread of the infection to other leaves and collapse of the whole plant. Values are averages and standard deviations of data pooled from three independent experiments with similar results. this host was significantly lower $(P<$ $0.0001)$ than those observed for watermelon and melon (Table 3 ).

Fruit pathogenicity assays. Inoculation of mature, detached watermelon and melon fruits with different isolates resulted in a wide range of typical BFB symptoms (Fig. 3). External symptoms varied from small, restricted water-soaked areas to large, blackened water-soaked blotches. Internal fruit symptoms ranged from small lesions that barely penetrated the rind to complete rot of the fruit. In some cases, minor external symptoms were accompanied by extensive internal fruit rot, especially in melon. None of the fruits inoculated with sterile water developed BFB symptoms.

Two experiments were carried out, both including inoculation with two bacterial concentrations, $10^{6}$ and $10^{8} \mathrm{CFU} / \mathrm{ml}$. Although a similar trend of differential aggressiveness among isolates was observed at both inoculum concentrations, the differences were more evident at the lower concentration (Fig. 3), since as expected, at $10^{8} \mathrm{CFU} / \mathrm{ml}$, all isolates caused more severe symptoms (data not shown). The effects of experiment (inoculation at $10^{6}$ $\mathrm{CFU} / \mathrm{ml}$ ) on BFB severity was not significant $(P=0.37$ and 0.44 for melon and watermelon, respectively); hence, data from the two experiments was pooled. In general, $\mathrm{W}$ isolates showed higher aggressiveness in watermelon than in melon fruits, whereas the opposite was observed for $\mathrm{M}$ isolates (Fig. 3). Differences in aggressiveness on different hosts were more pronounced within $\mathrm{W}$ isolates, because these were found to be consistently less aggressive on melon than $\mathrm{M}$ isolates. In contrast, several M isolates (M5 and M6) were found to be highly aggressive on both melon and watermelon fruits, and disease severity in watermelon fruits inoculated with these isolates was as high as in fruits inoculated with $\mathrm{W}$ isolates (Fig. 3). These results agree with findings from seedling

Table 3. Summary of the results of seed pathogenicity assays of Acidovorax avenae subsp. citrulli isolates ${ }^{\mathrm{a}}$

\begin{tabular}{|c|c|c|c|c|c|c|}
\hline \multirow[b]{2}{*}{ Isolate } & \multicolumn{2}{|c|}{ Watermelon cv. Malali } & \multicolumn{2}{|c|}{ Melon cv. 6404} & \multicolumn{2}{|c|}{ Cucumber cv. Olympus } \\
\hline & $\begin{array}{l}\text { Symptomatic } \\
\text { seedlings }(\%)\end{array}$ & $\begin{array}{c}\text { Seedling death } \\
(\%)\end{array}$ & $\begin{array}{l}\text { Symptomatic } \\
\text { seedlings }(\%)\end{array}$ & $\begin{array}{c}\text { Seedling death } \\
(\%)\end{array}$ & $\begin{array}{l}\text { Symptomatic } \\
\text { seedlings }(\%)\end{array}$ & $\begin{array}{c}\text { Seedling death } \\
(\%)\end{array}$ \\
\hline W1 & 10 & 10 & 0 & 0 & 75 & 0 \\
\hline W2 & 61 & 12 & 35 & 5 & 75 & 0 \\
\hline W3 & 5 & 0 & 7 & 0 & 63 & 25 \\
\hline W4 & 25 & 0 & 0 & 0 & 30 & 0 \\
\hline W5 & 10 & 0 & 0 & 0 & 40 & 0 \\
\hline W6 & 15 & 0 & 20 & 10 & 40 & 0 \\
\hline $\mathrm{W}_{\mathrm{Av}}$ & 21.0 & 3.7 & 10.3 & 2.5 & 53.8 & 4.2 \\
\hline M1 & 85 & 85 & 90 & 90 & 100 & 30 \\
\hline M2 & 90 & 80 & 90 & 90 & 90 & 25 \\
\hline M3 & 90 & 90 & 95 & 80 & 100 & 20 \\
\hline M4 & 80 & 77 & 83 & 50 & 100 & 13 \\
\hline M5 & 92 & 72 & 95 & 89 & 100 & 14 \\
\hline M6 & 85 & 90 & 93 & 79 & 100 & 0 \\
\hline $\mathrm{M}_{\mathrm{Av}}$ & 87.0 & 82.3 & 91.0 & 79.7 & 98.3 & 17.0 \\
\hline
\end{tabular}

a Percentages of symptomatic seedlings and of seedling death occurrence as assessed 18 days after inoculation. Values are averages of data pooled from two independent experiments (24 plants per treatment per experiment). The two groups ( $\mathrm{W}_{\mathrm{Av}}$ and $\mathrm{M}_{\mathrm{Av}}$ ) differed significantly $(P<0.0001)$ for all parameters in all tested plants. 
pathogenicity assays, in which M5 and M6 were among the most aggressive isolates.

DNA fingerprinting by SpeI digestion and PFGE. Using PFGE, Walcott et al. $(25,27)$ reported 24 differentiated $A$. avenae subsp. citrulli haplotypes, 12 within each group (I and II), which were designated A through $\mathrm{X}$, following the order in which they were first observed. Because of the high reproducibility of PFGE, DNA fingerprinting profiles from these studies could be compared with ours.

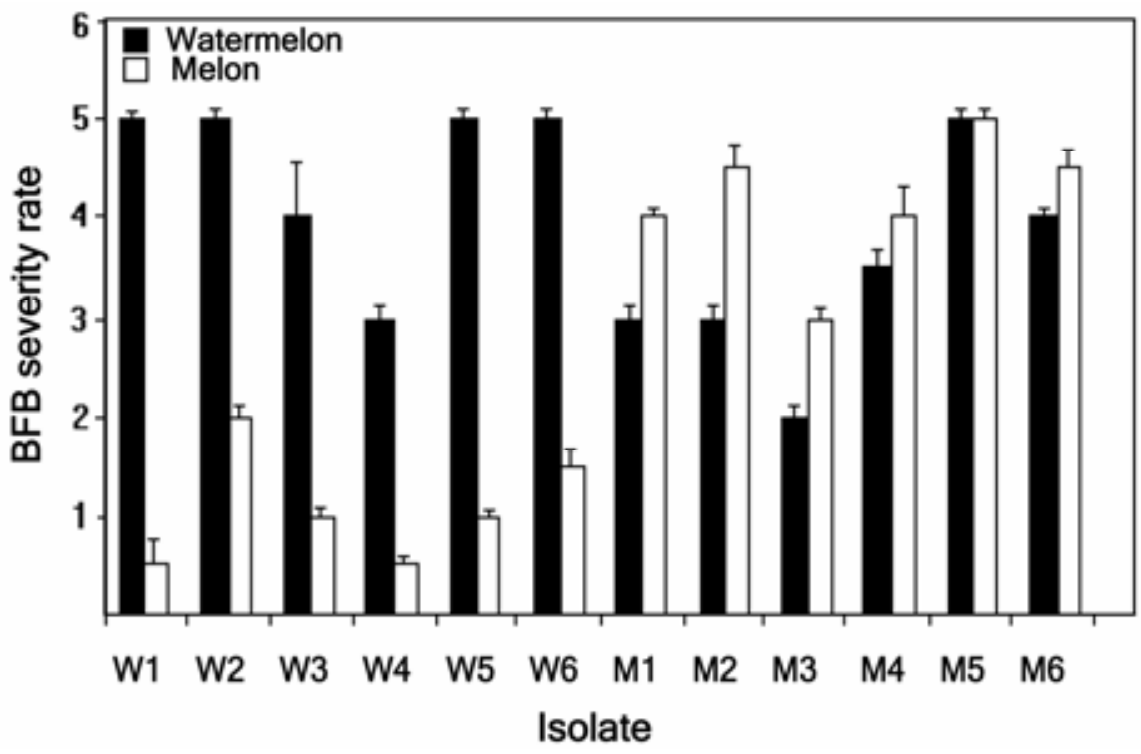

Fig. 3. Bacterial fruit blotch (BFB) severity of detached watermelon (cv. Crimson Sweet) and melon (Ananas type) fruits inoculated with Acidovorax avenae subsp. citrulli isolates at $10^{6} \mathrm{CFU} / \mathrm{ml}$. Bars and lines represent average severity ratings and standard deviations, respectively, from two independent experiments that yielded similar results. In each experiment, each isolate was injected into three fruits (replicates) at four and two different sites for watermelon and melon, respectively. Symptom severity was evaluated 7 days after inoculation according to the following scale: 0 , no symptoms; 1 , small water-soaking lesions on the rind (surface lesions); 2 , large lesions penetrating into the rind; 3 , lesions penetrating into the flesh of the fruit; 4 , extensive penetration and collapse of fruit tissues; 5 , complete fruit rot.

PFGE analyses revealed 23 unique DNA fragments and five different profiles, each one containing 9 to 13 bands (Fig. 4). Of these profiles, four were previously unreported. The corresponding new haplotypes were designated $\mathrm{Y}, \mathrm{Z}, \mathrm{E} 2$, and E3. Isolates M1 to M6 could be clearly classified as group I isolates, while W1 to W6 clearly belonged to group II.

Isolates M1 to M6 had identical DNA fingerprinting profiles, and thus belong to a single haplotype. This haplotype was previously unreported and, following the alphabetical order, was designated Y. Although this haplotype shares similarities with the previously reported group I haplotypes $\mathrm{R}, \mathrm{V}$, and $\mathrm{X}(25)$, it can be clearly distinguished from them based on several differential bands (Fig. 4).

The $\mathrm{W}$ isolates included four different group II profiles (Fig. 4). W1 and W3 belonged to the previously reported haplotype A (27), whereas the other isolates belong to three previously unreported haplotypes. W6 had a unique profile, with some similarities with the reported haplotypes D and J (27) (Fig. 4). This new haplotype was designated $\mathrm{Z}$. Isolates $\mathrm{W} 4$ and W5 were shown to possess identical profiles, and shared high similarities with the reported haplotype E (27) (Fig. 4). The new haplotype was named E2. Finally, W2 also showed an unreported profile. Because the W2 profile showed similarities with those of haplotypes E and E2 (Fig. 4), this new haplotype was designated E3.

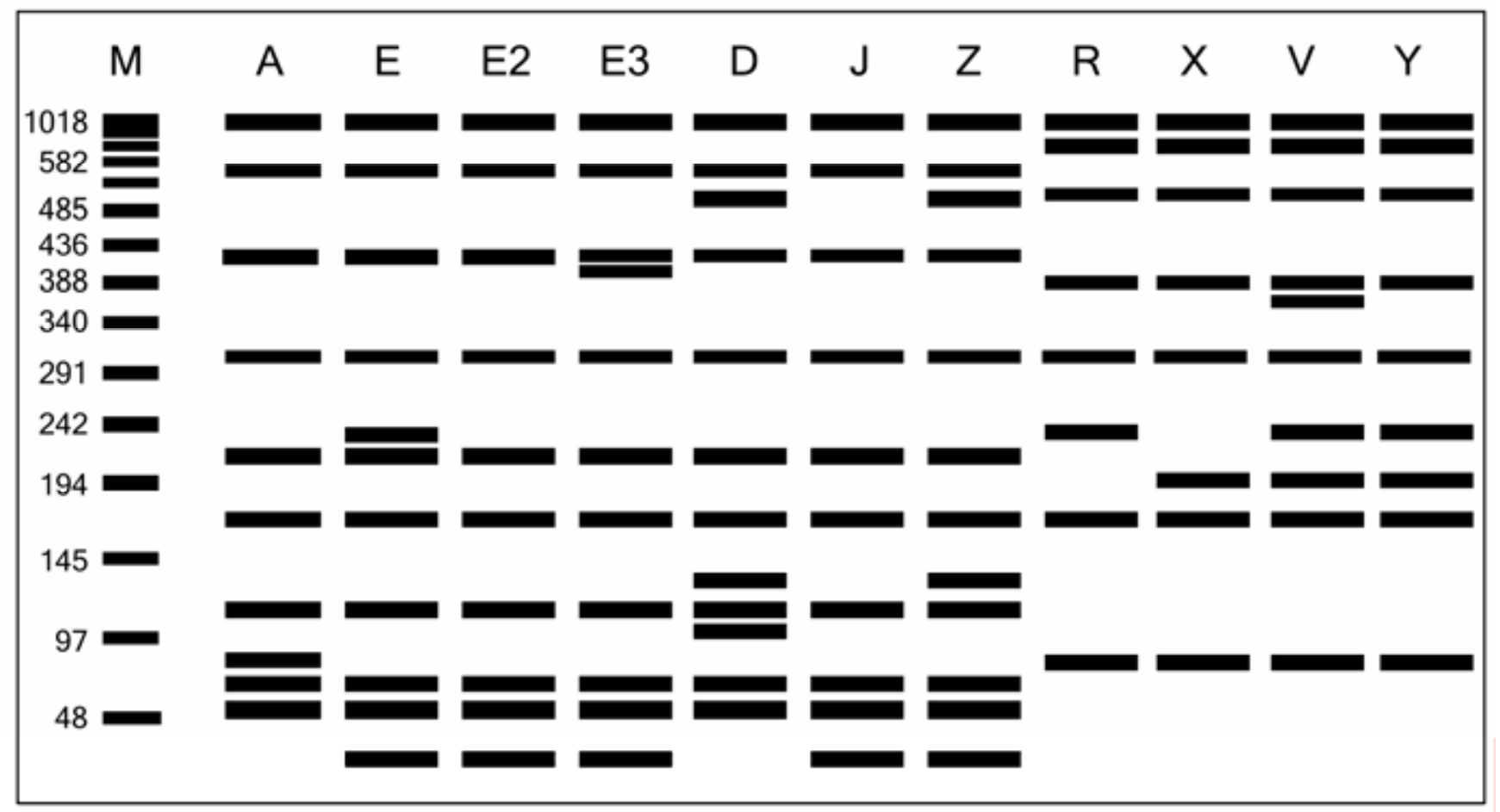

Fig. 4. Diagram of DNA fingerprinting haplotypes of Acidovorax avenae subsp. citrulli isolates by pulsed-field gel electrophoresis (PFGE) following DNA digestion with SpeI. M, concatemeric lambda DNA (New England Biolabs). Haplotypes identified in this study (isolates between brackets): E2 (W4 and W5); E3 (W2); Z (W6); and Y (M1 to M6). Haplotype A was previously reported (27) and includes isolates W1 and W3. Haplotypes D, E, and J (27), as well as R, $\mathrm{X}$, and V (25), are included for comparison. 
Rep-PCR fingerprinting. It has previously been shown that BOX-PCR can be used to distinguish between group I and II strains (25). A similar observation was made in our study, in which $\mathrm{M}$ and $\mathrm{W}$ isolates showed clearly differentiated BOXPCR profiles (Fig. 5). Despite the typical reproducibility limitations of PCR-based fingerprinting techniques, BOX-PCR profiles from both studies were comparable, and this comparison supported the distribution of $\mathrm{M}$ and $\mathrm{W}$ isolates into groups $\mathrm{I}$ and II, respectively. In addition, similarly to BOX-PCR, ERIC- and REP-PCR clearly distinguished between $\mathrm{M}$ and $\mathrm{W}$ isolates (Fig. 5). In general, differences among $\mathrm{M}$ and $\mathrm{W}$ isolate profiles were more pronounced in BOX- and ERIC-PCR than in REP-PCR.

In all approaches, differences between $\mathrm{M}$ and $\mathrm{W}$ isolates included amplification of unique, group-specific DNA fragments such as the 2.0-, 1.2-, 0.8-, and 0.45-kb fragments in BOX-PCR, the 1.7- and $0.25-\mathrm{kb}$ fragments in ERIC-PCR, and the 0.7 - and $0.35-\mathrm{kb}$ fragments in REP-PCR. In addition, $M$ and $\mathrm{W}$ profiles shared several fragments with similar moieties but that were amplified at different intensities, such as the $1.0-\mathrm{kb}$ fragment in BOX-PCR, the 1.1-kb fragment in ERIC$\mathrm{PCR}$, and the 1.0-kb fragment in REPPCR (Fig. 5).

As expected from the PFGE results, all $M$ isolates showed identical Rep-PCR profiles. However, no Rep-PCR technique was able to distinguish among the $\mathrm{W}$ isolates that were previously shown to belong to four different haplotypes based on PFGE (Fig. 5).

\section{DISCUSSION}

Until 1996, BFB was considered a serious threat mainly for the watermelon industry. It is likely that recent increases in BFB's occurrence on nonwatermelon cucurbits worldwide are due to changes in the population structure and spread of the pathogen (25). Diversity among populations of $A$. avenae subsp. citrulli was revealed by Somodi et al. (23), who reported that strains isolated from the late 1980 s BFB outbreaks in the United States differed in several features from the ATCC type strain isolated in 1978 (22). Eight years later, O'Brien and Martin (18) distinguished between two distinct groups of A. avenae subsp. citrulli strains from Australia based on differences in pathogenicity and in L-leucine and 2-amino ethanol utilization. Recently, based on an extensive characterization of strains, Walcott et al. $(25,27)$ confirmed the existence of at least two genetically distinct groups within this bacterium: group I included strains that were mainly isolated from nonwatermelon cucurbits such as melon and pumpkin, and group II included the typical watermelon BFB-causing strains. Our findings support this division and revealed that isolates from both groups have been introduced into Israeli fields.

DNA fingerprinting by PFGE following SpeI digestion revealed that the 12 isolates belong to five different haplotypes, which could be clustered into the two defined $A$. avenae subsp. citrulli groups. Isolates from watermelon showed a higher degree of heterogeneity than melon isolates, consisting of four different haplotypes. Whereas $\mathrm{W} 1$ and W3 belong to the previously reported haplotype A (27), the other isolates belong to three different, previously unreported haplotypes. In contrast, isolates from melon were found to be monogenic, consisting of a single haplotype that had not been previously reported. Despite iden- tical PFGE profiles, isolates M1 to M6 could be differentiated by substrateutilization profiles and aggressiveness. Similar findings were observed for isolates W1 and W3 (haplotype A) and W4 and W5 (haplotype E2). This indicates that differences in pathogenicity and in biochemical properties between isolates go beyond their genomic haplotype classification. In other words, haplotype does not necessarily reflect strain aggressiveness.

The present study shows that ERIC- and REP-PCR can efficiently distinguish between group I and II strains of A. avenae subsp. citrulli, as reported for BOX-PCR (25). However, we found that all repetitivePCR (Rep-PCR) techniques are less sensi-
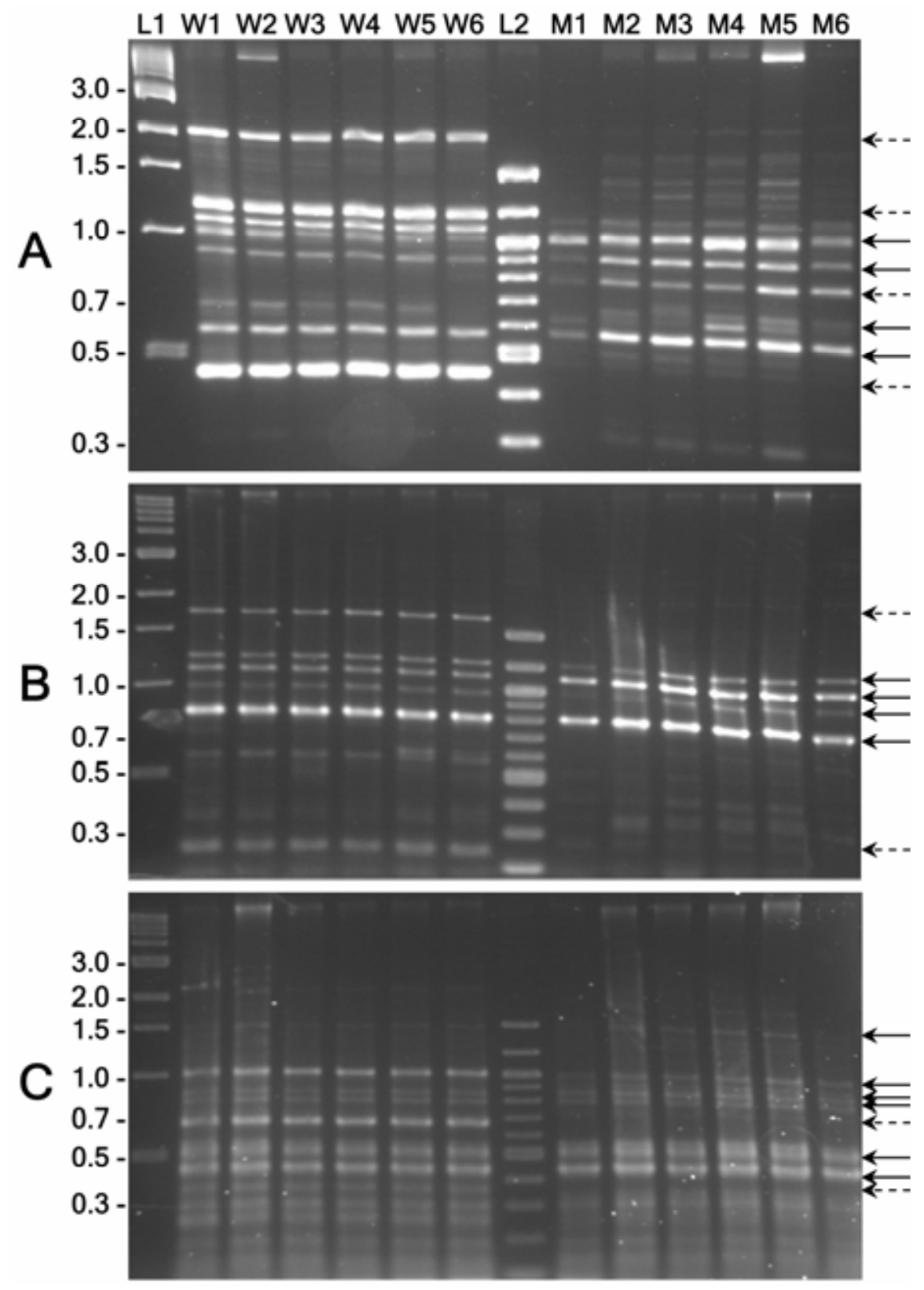

Fig. 5. DNA fingerprinting of Acidovorax avenae subsp. citrulli isolates by Repetitive-PCR (RepPCR) techniques. A, BOX-PCR. B, ERIC-PCR. C, REP-PCR. Lanes 1 (L1) and 8 (L2) were loaded with 1-kb and 100-bp ladders (New England Biolabs), respectively. Solid arrows indicate major bands with similar moiety within $\mathrm{W}$ and $\mathrm{M}$ isolates; dashed arrows indicate unique, group-specific DNA fragments. 
tive than PFGE in distinguishing among different isolates belonging to the same group. This conclusion is based on the fact that $\mathrm{W}$ isolates belonging to four different group II haplotypes on the basis of PFGE analysis could not be distinguished by their BOX-, ERIC-, and REP-PCR profiles.

PFGE and Rep-PCR are among the most powerful DNA fingerprinting approaches for identification and characterization of bacteria. The most significant advantage of PFGE resides in its reproducibility. RepPCR approaches have the advantage of being more accessible, less expensive, and faster than PFGE. However, Rep-PCR is subject to experimental limitations and may lead to reduced levels of reproducibility. Furthermore, although Walcott et al. (25) did distinguish between group I and II isolates by BOX-PCR, they reported that several DNA amplicons were difficult to score. Therefore, it can be concluded that Rep-PCR can be used to distinguish between group I and group II isolates, but PFGE is preferable if the objective is to assess the genetic diversity occurring between strains. On the other hand, the relatively high degree of conservation observed for the Rep-PCR profiles of different isolates (including several fragments that appear to be amplified from both group I and II isolates) can be exploited for the development of more specific PCR-based methods for the detection of $A$. avenae subsp. citrulli, for which a high demand exists $(21,26)$.

Overall, the results from pathogenicity assays corresponded to the genetic differentiation between $\mathrm{W}$ and $\mathrm{M}$ isolates, and were in general agreement with previous reports on differences in pathogenicity between group I and group II strains $(18,23,25,27)$. In general, watermelon was more susceptible to $A$. avenae subsp. citrulli than melon in seedling and fruit pathogenicity assays. As previously reported for group II strains, W1 through W6 were more aggressive on watermelon than on nonwatermelon hosts. Also consistent with previous reports was the fact that no obvious differences were observed between different host plants in disease severity as induced by $M$ isolates, although a trend of increased severity was observed for melon fruits inoculated with these isolates compared with watermelon fruits.

Seedling inoculation by rubbing leaves and/or cotyledons with (or without) Carborundum and inoculation of detached fruit by bacterial injection are wellaccepted methods for the investigation of foliar diseases caused by plant pathogenic bacteria (9). These techniques were also used in previous studies involving inoculation of seedlings $(4,29)$ and detached fruits $(23,24,28)$ with $A$. avenae subsp. citrulli. However, it is important to state that, as with every artificial inoculation technique, these methods have potential limitations. For instance, the utilized methods may obscure differences among isolates if motility plays an important role for bacterial penetration through natural openings such as stomata. Also, atypical symptoms may be produced with these methods (9). Hence, aggressiveness of isolates as determined in the present study may vary under natural conditions.

One of the most interesting findings from this study was the clear difference in aggressiveness among $\mathrm{M}$ and $\mathrm{W}$ isolates in seed transmission assays, where $\mathrm{M}$ isolates showed a significantly higher aggressiveness, on watermelon as well. Microscopic observations of the different isolates, performed during growth curve experiments and inoculum preparation, revealed that $\mathrm{M}$ isolates possess a consistently higher motility than $\mathrm{W}$ isolates (not shown). It is well-established that in addition to motility, bacterial flagella play an important role in bacteria's surface attachment and adhesion (17). A possibility exists that $\mathrm{M}$ isolates were able to adhere and anchor to seed surfaces in a more efficient way and remained attached to the seeds at higher levels than $\mathrm{W}$ isolates after seed washings and/or during the first days after sowing. Further studies, however, are required to verify if motility and flagella have a role in aggressiveness of $A$. avenae subsp. citrulli in seed transmission.

Walcott et al. (25) reported L-leucine and $\alpha$-hydroxybutyric acid as sole carbon substrates differentially utilized by group I and group II strains: according to that study, 26 of $27(96.3 \%)$ group II strains utilized L-leucine, while only one (the ATCC type strain) out of 28 (3.6\%) group I strains utilized this substrate. Percentages of $\alpha$-hydroxybutyric acid utilization were $85.2 \%(23 / 27)$ and $28.6 \%$ (8/28) for group II and group I strains, respectively (25). Our results agree with that finding since all $\mathrm{W}$ isolates, but not $\mathrm{M}$ isolates, were shown to utilize these substrates. It seems that several corrections are needed in the Biolog database, which currently indicates that no A. avenae subsp. citrulli strain is expected to grow in L-leucine. Similarly, five of the $\mathrm{W}$ isolates utilized D-glucose, whereas utilization of this substrate by $A$. avenae subsp. citrulli is not predicted by the Biolog database. In addition to Lleucine and $\alpha$-hydroxybutyric acid, all group II isolates from our study utilized propionic acid, $\alpha$-keto valeric acid, and alaninamide, while no group I isolate utilized these substrates.

This study contributes additional features that can be used to distinguish between group I and II strains. W and M isolates showed slight differences in their growth curves in NB, and clear differences between the two classes of isolates were observed in tolerance to rifampicin and extracellular cellulase activity. In contrast, no significant differences were found among isolates in terms of extracellular protease and pectinase activities, and no isolate was able to hydrolyze starch. Whereas negative starch hydrolysis, positive protease activity, and the ability to utilize cellulose have been previously shown for $A$. avenae subsp. citrulli $(22,27)$, to the best of our knowledge, this is the first study to demonstrate pectinase extracellular activities for this bacterium. Whether these features play a significant role in A. avenae subsp. citrulli virulence still needs to be assessed. Also, due to the relatively low number of isolates available for our study, we cannot state with high confidence that all differences found between $\mathrm{M}$ and $\mathrm{W}$ isolates in this work reflect features differentiating the two groups on a broader scale. Since A. avenae subsp. citrulli is a quarantined bacterium in Israel, rigid regulations prohibit its introduction from abroad, thereby limiting the number of strains available for investigation.

The interesting question remains as to whether the recent BFB occurrence in Israel was due to single events of pathogen introduction, or whether A. avenae subsp. citrulli was already present in the country and suitable environmental conditions led to disease development during the early 2000s. During the 1990s, there were several events of $A$. avenae subsp. citrulli detection by the Israeli Quarantine authorities, including some from noncucurbit hosts $(1,2)$. Since there is a lack of efficient tools for detection of the pathogen, it is plausible that the pathogen could have escaped detection in seed lots with low levels of infestation. This, together with the fact that environmental conditions during the early 2000s (and especially in 2002) particularly encouraged bacterial foliar diseases, and that BFB occurred in both watermelon and melon, suggest that BFB's occurrence was not due to a single introduction event. It is more likely that the A. avenae subsp. citrulli strains were introduced into the country more often than assumed, and/or that the pathogen was already present, "waiting" for simultaneous occurrence of the three known plant-disease prerequisites: pathogen, host, and favorable environment. The relative haplotype diversity observed among the characterized haplotypes also supports this possibility.

It is still too early to predict the impact of $\mathrm{BFB}$ on watermelon and melon production in Israel. Although economic losses caused by BFB were limited to a few fields, growers are concerned about the disease because of its destructive potential. Moreover, BFB is considered a serious threat for local seedling nurseries and seed companies, particularly those producing watermelon and melon seeds for export. The lack of efficient pathogen detection assays, and the fact that A. avenae subsp. citrulli-infested plants can be asymptomatic under suboptimal conditions for disease development, add to this serious concern. 


\section{ACKNOWLEDGMENTS}

We thank Israel Ben-Zeev from the Israeli Plant Protection and Inspection Services for his contribution with GC-FAME analysis of the isolates, and Hillary Voet for her valuable assistance with statistical analysis. We also thank Iosi Fuxenbaum (Hazera Genetics Co., Israel) and Dror Weiss (CTS Co., Israel) for kindly supplying seeds for this study, as well as Prof. Jaacov Katan for his valuable comments during the preparation of this manuscript. This study was partially supported by grant number 823018005 from the Chief Scientist and from the Vegetable Division of the Israeli Ministry of Agriculture, and by the Robert Szold Fund.

\section{LITERATURE CITED}

1. Assouline, I. 1996. The watermelon fruit blotch and other diseases caused by Acidovorax avenae. Phytoparasitica 24:136-137.

2. Assouline, I., Milshtein, H., Mizrachi, M., Levy, E., and Ben-Ze'ev, I. S. 1997. Acidovorax avenae subsp. citrulli transmitted by Solanaceous seeds. Phytoparasitica 25:2.

3. Ausubel, F. M., Brent, R., Kingston, R. E., Moore, D. D., Seidman, J. G., Smith, J. A., and Struhl, K. 1994. Current Protocols in Molecular Biology. John Wiley \& Sons, New York.

4. Goth, R. W., and Webb, R. E. 1981. Resistance of commercial watermelon (Citrullus lanatus) to Pseudomonas pseudoalcaligenes subsp. citrulli. Plant Dis. 65:671-672.

5. Hopkins, D. L., Cucuzza, J. D., and Watterson, J. C. 1996. Wet seed treatments for the control of bacterial fruit blotch of watermelon. Plant Dis. 80:529-532.

6. Hopkins, D. L., and Thompson, C. M. 2002. Seed transmission of Acidovorax avenae subsp. citrulli in cucurbits. Hortscience 37:924-926.

7. Isakeit, T., Black, M. C., Barnes, L. W., and Jones J. B. 1997. First report of infection of honeydew with Acidovorax avenae subsp. citrulli. Plant Dis. 81:694.

8. Isakeit, T., Black, M. C., and Jones, J. B. 1998. Natural infection of citron melon with Acidovorax avenae subsp. citrulli. Plant Dis. 82:351.

9. Klement, Z., Mavridis, A., Rudolph, K., Vidaver, A., Pérombelon, M. C. M., and Moore, L. W. 1990. Inoculation of Plant Tissues. Pages 95-124 in: Methods in Phytobacteriology. Z.
Klement, K. Rudolph, and D. C. Sands, eds. Akadémiai Kiadó, Budapest.

10. Kucharek, T., Perez, Y., and Hodge, C. 1993. Transmission of the watermelon fruit blotch bacterium from infested seed to seedlings. (Abstr.) Phytopathology 83:466.

11. Langston, D. B., Jr., Walcott, R. D., Gitaitis, R. D., and Sanders, F. H., Jr. 1999. First report of a fruit rot of pumpkin caused by Acidovorax avenae pv. citrulli in Georgia. Plant Dis. 83:199

12. Latin, R., and Hopkins, D. L. 1995. Bacterial fruit blotch of watermelon: The hypothetical question becomes reality. Plant Dis. 79:761-765.

13. Latin, R. X., and Rane, K. K. 1990. Bacterial fruit blotch of watermelon in Indiana. Plant Dis. 74:331.

14. Louws, F. J., Fulbright, D. W., Stephens, C. T., and De Bruijn, F. J. 1994. Specific genomic fingerprintings of phytopathogenic Xanthomonas and Pseudomonas pathovars and strains generated with repetitive sequences and PCR. Appl. Environ. Microbiol. 60:2286-2295.

15. Martin, H. L., O'Brien, R. G., and Abbott, D. V. 1999. First report of Acidovorax avenae subsp. citrulli as a pathogen of cucumber. Plant Dis. 83:965.

16. Miller, L. T. 1982. Single derivation method for routine analysis of bacterial whole-cell fatty acid methyl esters, including hydroxyl acids. J. Clin. Microbiol. 16:584-586.

17. Moens, S., and Vanderleyden, J. 1996. Functions of bacterial flagella. Crit. Rev. Microbiol. 22:67-100.

18. O'Brien, R. G., and Martin, H. L. 1999. Bacterial blotch of melons caused by strains of Acidovorax avenae subsp. citrulli. Aust. J. Exp. Agric. 39:479-485

19. Rane, K. K., and Latin, R. X. 1992. Bacterial fruit blotch of watermelon: Association of the pathogen with seed. Plant Dis. 76:509-512.

20. Sambrook, J., Fritsch, E. F., and Maniatis, T. 1989. Molecular Cloning: A Laboratory Manual. Cold Spring Harbor Laboratory, Cold Spring Harbor, NY.

21. Schaad, N. W., Postnikova, E., and Randhawa, P. 2003. Emergence of Acidovorax avenae subsp. citrulli as a crop threatening disease of watermelon and melon. Pages 573-581 in: Pseudomonas syringae and Related Pathogens -
Biology and Genetics. N. S. Iacobellis, A. Collmer, S. W. Hutcheson, J. W. Mansfield, C. E. Morris, J. Murillo, N. W. Schaad, D. E. Stead, G. Surico, and M. S. Ullrich, eds. Kluwer Academic Publishers, Dordrecht, Netherlands.

22. Schaad, N. W., Sowell, G., Goth, R. W. Colwell, R. R., and Webb, R. R. 1978. Pseudomonas pseudoalcaligenes subsp. citrullis subsp. nov. Int. J. Syst. Bacteriol. 28:117-125.

23. Somodi, G. C., Jones, J. B., Hopkins, D. L., Stall, R. E., Kucharek, T. A., Hodge, N. C., and Watterson, J. C. 1991. Occurrence of bacterial watermelon fruit blotch in Florida. Plant Dis. 75:1053-1056.

24. Sowel, G., Jr., and Schaad, N. W. 1979. Pseudomonas pseudoalcaligenes subsp. citrulli on watermelon: Seed transmission and resistance of plant introductions. Plant Dis. Rep. 63:437441.

25. Walcott, R. R., Fessehaie, A., and Castro, D. 2004. Differences in pathogenicity between two genetically distinct groups of Acidovorax avenae subsp. citrulli on cucurbit hosts. J. Phytopathol. 152:277-285.

26. Walcott, R. R., and Gitaitis, R. D. 2000. Detection of Acidovorax avenae subsp. citrulli in watermelon seed using immunomagnetic separation and the polymerase chain reaction. Plan Dis. 84:470-474.

27. Walcott, R. R., Langston, D. B., Jr., Sanders, F. H., Jr., and Gitaitis, R. D. 2000. Investigating intraspecific variation of Acidovorax avenae subsp. citrulli using DNA fingerprinting and whole fatty cell acid analysis. Phytopathology 90:191-196.

28. Wall, G. C., and Santos, V. M. 1988. A new bacterial disease on watermelon in the Mariana Islands. (Abstr.) Phytopathology 78:1605.

29. Webb, R. E., and Goth, R. W. 1965. A seedborne bacterium isolated from watermelon. Plant Dis. Rep. 49:818-821.

30. Willems, A., Goor, M., Thielemans, S., Gillis, M., Kersters, K., and De Ley, J. 1992. Transfer of several phytopathogenic Pseudomonas species to Acidovorax avenae subsp. nov., comb. Nov., Acidovorax avenae subsp. citrulli, Acidovorax avenae subsp. cattleyae and Acidovorax avenae subsp. konjaci. Int. J. Syst. Bacteriol. 42:107-119. 